Jurnal Keperawatan Padjadjaran

ISSN 2338-5324 (print)

ISSN 2442-7276 (online)

Online di http://jkp.fkep.unpad.ac.id

DOI : $10.24198 / \mathrm{jkp}$

\title{
The Effect of Reciting the Holy Qur'an to the Speaking Ability and Spirituality Level of Stroke Patient with Motor Aphasia
}

\author{
Slamet Purnomo', Ikhlas M Jenie ${ }^{2}$ \\ ${ }^{1}$ Faculty of Health Sciences, Universitas Muhammadiyah Kalimantan Timur, Samarinda, Indonesia \\ ${ }^{2}$ Faculty of Medicine and Health Sciences, Universitas Muhammadiyah Yogyakarta, Yogyakarta, \\ Indonesia \\ Corresponding Email: pslametpurnomo@yahoo.co.id
}

Submitted: 18-08-2020 Accepted: 05-11-2020 Published: 01-12-2020

\begin{abstract}
Reading therapy is a stimulation effort to improve language function of a patient with motor aphasia. This study aim was to examine the effect of reading therapy using holy Qur'an to the speaking ability and spirituality level of stroke patient with aphasia. This experimental study used nonequivalent control group design with 20 persons as sample, divided to 10 persons as the intervention group and 10 persons in the control group used purposive sampling technique. Measurement of the speaking ability used Frenchay Aphasia Screening Test (FAST) questionnaire and spirituality level used Functional Assessment of Chronic Illness Therapy (FACIT) Sp 12 questionnaire. The Result was significant improvement of speaking ability in the intervention group with mean difference was mean \pm SD $(1,60 \pm 1,075)$. Post-experimental difference test showed the difference of improvement of speaking ability between two groups, $\mathrm{P}=0,034$. The spirituality level also significantly improved in the intervention group with mean difference was mean $\pm \mathrm{SD}(6,80 \pm 3,190)$. Post experimental difference test showed the improvement of spirituality level in both groups with $\mathrm{P}=0,005$. This therapy can be used as a rehabilitation training activity independently at home to improve the speaking ability also as part of spiritual activity.
\end{abstract}

Keywords: Aphasia, reciting Qur'an, speaking ability, spirituality. 


\section{Introduction}

The brain has an important role in human evolution. Vascularization problem at the brain will destroy its function which can cause a stroke. Stroke was at the second level of the causing death disease in the world, with 6.7 million of mortality each year (WHO, 2015). In Indonesia, stroke was at the third place the most common disease after heart disease and cancer. Data the Indonesian Health Profile mentioned that about 57.9\% of stroke disease have been diagnosed by the healthcare professional (Ministry of Health Indonesia, 2018).

Stroke can lead to death in about $28.5 \%$ patients, while remaining of them suffered for partial or total paralysis. Furthermore, only about $15 \%$ of them can be fully recovered from the stroke attack and disability (Khairunnisa \& Fitriyani, 2014). It has been estimated that about $21-38 \%$ stroke patient will have risk for aphasia (Lazar \& Boehme, 2017). A study from one hospital at Indonesia showed that $13.2 \%$ of patients suffered for aphasia (Purnomo et al., 2016). A disability such as language and communication disorder in aphasia was the common problem in stroke patient (Palmer et al., 2015).

Reading-based therapy was a rehabilitative effort for the aphasia patient (Purnomo \& Makiyah, 2019). Reading therapy is an effort to stimulate and improve the patient's language function (Singh \& Pauranik, 2017). This strategy targets for improving in idea, verbal to verbal process, and improving reading ability which the treatment focused was reading method (Richard, 2016).

Similar study using the Qur'an with the listening and memorizing method has had a positive effect on recovery (Jafar et al., 2019; Sofro \& Kadarsih, 2013). While, research using the holy Qur'an with the reading method in motor aphasia has not been developed much. Several studies about reading based therapy in aphasia patients used novel or other demonstration sentences as resources (Kim \& Lemke, 2016; Richard, 2016). In fact, the majority of Indonesian citizen were Moslem. This big gap became a consideration to raise the study about holy Qur'an therapy as an alternative therapy to solve the speaking problem in aphasia patients.

Furthermore, there was a special thing that holy Qur'an had compared to others books or other reading material. The sound and rhythm from Qur'an phonetic (tajweed) produced a special voice through the letter and words management in holy Qur'an when reciting or verbalize Qur'an with voice (Kalani et al., 2016). Those things are useful to give a stimulation for sensory and motor function which will be good to be used in speaking disorder rehabilitation training. Also, reciting the holy Qur'an is a religious activity which can improve the patient's spirituality.

Patient's ill problem should not only be viewed from the physical problem, but more holistic view through bio-psycho-social and spiritual view with their mission a servant of Allah and caliph of Allah's in life. However, further empirical evidence was needed through this study to gain more knowledge about it.

\section{Method}

This study was quasi-experimental study used nonequivalent control group design, which using reciting the holy Qur'an as a treatment for the intervention group and observation in control group. This study has been approved an ethical clearance from Ethical committee of Abdul Wahab Sjahranie Samarinda Regional Public State Hospital no: 041/ KEPK-AWS/III/2019 and ethical committee of Universitas 'Aisiyah Yogyakarta no: 948/ KEP-UNISA/III/2019.

Participants have been selected using a purposive sampling technique, which is sampling based on specific consideration according to the study purpose and criteria. Inclusion criteria were; ischemia stroke patient after 1 week or more attack experience, had motor aphasia, and able to receive direction. Exclusion criteria were critical condition and unstable hemodynamic state. Only 20 persons of the patients have been fulfilled the criteria to be respondents. 20 respondents have been divided into two groups, 10 persons in the intervention group, and 10 persons in the control group. The study did not randomize the respondent because there's a limitation related to amount of samples. It has been 
Slamet Purnomo: The Effect of Reciting the Holy Qur'an to the Speaking Ability and Spirituality Level of Stroke

suggested for the future study to include more respondents for gathering more various result.

This study has been conducted in April 2019 at the patient's home based on the data from Abdul Wahab Sjahranie Samarinda Regional Public State Hospital. The Intervention group try to reciting holy Qur'an surah Al-Fatihah, Al-Ikhlas, Al-Falaq and An-Naas and the other group (control group) receives the regular rehabilitation base on schedule from the hospital.

The Treatment for intervention group has been given in 12 meeting sessions in two weeks. Respondents have been given rest time for 1 day in each week. The duration of intervention in each session is about 1520 minutes per day and led by the researcher than participant repeating the reciting Qur'an after researcher to reach appropriate rule of reciting Qur'an (tajweed). In conducting this study, researcher has passed the holy Qur'an test from Islamic Studies and Experience Institution (LPPI) from Universitas
Muhammadiyah no: 001/A.4-1/LPPI/I/2019. Measurement for the speaking ability used Frenchay Aphasia Screening Test (FAST) questionnaire and Functional Assessment of Chronic Illness Therapy (FACIT) Sp 12 questionnaire for spirituality level measure. The measurement process has been done before intervention and two weeks after intervention. Both of measurements have been standardized and translated to Indonesian Language. The finding results have been analyzed used statistical program SPSS 20.0 version. Univariate analysis used for the data included sex, education, stroke frequency and other accompanying disease which presented in mean, deviation standard and minimum-maximum value. The bivariate analysis used the parametric test (paired $\mathrm{t}$-test and independent t-test) to evaluate the effectiveness of therapy.

\section{Results}

Table 1 Distribution of Demographic Characteristics of Respondents

\begin{tabular}{|c|c|c|c|c|c|}
\hline \multirow{2}{*}{ Characteristics } & \multicolumn{2}{|c|}{ Intervention Group $(n=10)$} & \multicolumn{2}{|c|}{$\begin{array}{c}\text { Control Group } \\
(\mathbf{n}=10)\end{array}$} & \multirow{2}{*}{ P value } \\
\hline & $\mathbf{F}$ & $\%$ & $\mathbf{F}$ & $\%$ & \\
\hline \multicolumn{6}{|l|}{ Sex } \\
\hline Male & 4 & 40 & 3 & 30 & 0.648 \\
\hline Female & 6 & 60 & 7 & 70 & \\
\hline \multicolumn{6}{|l|}{ Education } \\
\hline Primary school & 1 & 10 & 2 & 20 & 0.218 \\
\hline $\begin{array}{l}\text { Junior high } \\
\text { school }\end{array}$ & 3 & 30 & 5 & 50 & \\
\hline $\begin{array}{l}\text { Senior high } \\
\text { school }\end{array}$ & 4 & 40 & 2 & 20 & \\
\hline College & 2 & 20 & 1 & 10 & \\
\hline \multicolumn{6}{|l|}{$\begin{array}{l}\text { Stroke } \\
\text { frequency }\end{array}$} \\
\hline 1 time & 6 & 60 & 5 & 50 & 0.661 \\
\hline$>1$ time & 4 & 40 & 5 & 50 & \\
\hline \multicolumn{6}{|l|}{ Comorbidities } \\
\hline Hypertension & 9 & 64.3 & 8 & 53.3 & 0.484 \\
\hline $\begin{array}{l}\text { Diabetes } \\
\text { Mellitus (DM) }\end{array}$ & 5 & 35.7 & 7 & 46.7 & \\
\hline \multicolumn{6}{|l|}{ Age } \\
\hline Mean \pm SD & \multicolumn{2}{|c|}{$54.80 \pm 8.052$} & \multicolumn{2}{|c|}{$57.20 \pm 11.203$} & 0.589 \\
\hline
\end{tabular}


Slamet Purnomo: The Effect of Reciting the Holy Qur'an to the Speaking Ability and Spirituality Level of Stroke

\begin{tabular}{lccc}
\hline $\begin{array}{l}\text { Blood Pressure } \\
\text { Systolic }\end{array}$ & & & \\
Mean \pm SD & $148.50 \pm 12.756$ & $149.30 \pm 19.766$ & 0.916 \\
Diastolic & & & \\
Mean \pm SD & $96.90 \pm 3.281$ & $96.20 \pm 6.746$ & 0.771 \\
\hline
\end{tabular}

Table 2 Difference in Speaking Ability between the Intervention Group and Control Group

\begin{tabular}{lccccc}
\hline \multirow{2}{*}{$\begin{array}{c}\text { Speaking } \\
\text { Ability (FAST) }\end{array}$} & \multicolumn{2}{c}{$\begin{array}{c}\text { Intervention Group } \\
(\mathbf{n = 1 0})\end{array}$} & \multicolumn{2}{c}{$\begin{array}{c}\text { Control Group } \\
(\mathbf{n}=\mathbf{1 0})\end{array}$} & \multirow{2}{*}{ P value } \\
\cline { 2 - 5 } & Mean & SD & Mean & SD & \\
\hline Pre-test & 20.10 & 2.183 & 18.40 & 3.026 & 0.167 \\
Post-test & 21.70 & 3.020 & 18.80 & 2.616 & $0.034^{*}$ \\
Delta & 1.60 & 1.075 & 0.40 & 0699 & $0.008^{*}$ \\
\hline
\end{tabular}

*P value $<0.05$ based on the Independent-T test

The delta value is the difference between the post-test and pre-test results

Table 3 Difference in Spirituality Level between the Intervention Group and Control Group

\begin{tabular}{lccccc}
\hline \multirow{2}{*}{$\begin{array}{c}\text { Speaking } \\
\text { Ability (FAST) }\end{array}$} & \multicolumn{2}{c}{$\begin{array}{c}\text { Intervention Group } \\
(\mathbf{n}=\mathbf{1 0})\end{array}$} & \multicolumn{2}{c}{$\begin{array}{c}\text { Control Group } \\
(\mathbf{n}=\mathbf{1 0})\end{array}$} & \multirow{2}{*}{ P value } \\
\cline { 2 - 5 } & Mean & SD & Mean & SD & \\
\hline Pre-test & 31.60 & 4.789 & 30,70 & 5.376 & 0.697 \\
Post-test & 38.40 & 3.864 & 32,20 & 4.803 & $0.005^{*}$ \\
Delta & 6.80 & 3.190 & 1,50 & 1.780 & $0.001^{*}$ \\
\hline
\end{tabular}

*P value $<0.05$ based on the Independent-T test

The delta value is the difference between the post-test and pre-test results

Based on the Table 1, majority of respondents were male in the average age of 54 and 57 years old and most of them educated in Junior and Senior High School. Most of respondent experienced for the first attack of stroke. Furthermore, most of them had hypertension and diabetic mellitus as the accompanying disease. In blood pressure data, the average of systolic in intervention group was 148.50 and following by 149.30 in control group. In the other hand, the average of diastolic in intervention followed by the control group was 96.90 and 96.20.

Based on the upon table, the p-value was $p>0.05$ in all respondent characteristics for the differential test. The result showed that intervention and control group have same characteristic at baseline.

Result from table 2 showed that there was no significant difference in speaking ability in control and intervention group before the treatment (pre-test) with mean $\pm \mathrm{SD}$ in intervention group was $20.10 \pm 2.183$ and in control group was $18.40 \pm 3.026$.

The analysis result showed that there was significant improvement in speaking ability in intervention group compared with the control group with after treatment (post-test) with mean \pm SD was $21,70 \pm 3,020$ in intervention group and $18,80 \pm 2,616$ in control group.

Furthermore, there was a significant difference between pre and post treatment. It can be showed from the delta average mean was 1.60 in intervention group and was 0.40 in intervention group.

Result from Table 3 has shown that there was no significant difference in spirituality level between intervention and control group before treatment (pre-test) with mean \pm SD was $31.60 \pm 4.789$ in intervention group and $30.70 \pm 5.376$ in control group.

The result showed significant improvement 
of spirituality level after treatment (post-test) compared with control group with mean $\pm \mathrm{SD}$ was $38.40 \pm 3,864$ in intervention group and $32.20 \pm 4,803$ in control group.

Furthermore, there was a difference improvement in spirituality level before and after treatment. It can be showed that delta value was 6.80 in intervention group and 1.50 in control group.

\section{Discussion}

Patient's ill problem should not only be viewed from the physical problem, but more holistic view through bio-psycho-social and spiritual view with their mission a servant of Allah and caliph of Allah's in life. A nurse is required to be able to provide care to fulfilling these needs.

This study showed that motor activity through reciting the holy Qur' an can improve the speaking ability and spirituality level in stroke patient with motor aphasia.

Reading-based Therapy Using the Holy Qur'an in improving Speaking Ability. Basically, reading was a motor activity which can be used for training the speaking organ. The training principle was stimulating through speaking muscle training in order to improve language articulation more fluent in aphasia (Sofiatun et al., 2016). The motor movement which being created from articulation produced the sound as the same as reading which automatically will be received by the hearing system. The sound which produced by the reciting Qur'an then will stimulate parts of brain, which one of them was left brain (left hemisphere) which has function for managing the language and speaking function in the human (Mohamad et al., 2013).

This study supported by study from Jafar et al., (2019) which mentioned that the brain ability to re-manage through the brain neurons interconnection which influenced by the stimulation. A study on memorizing Qur'an Surah Taha verse 25-28th explained that can improve communication ability function. Stroke patients who always reciting and memorizing holy Qur'an will influence brain tissue neuroplasticity. The other supporting study Singh and Pauranik (2017) explained that stimulation using reading and writing approach will be benefit in improving verbal skill.

Result from this study showed that there was difference in speaking ability between intervention and control group. Alawieh et al. (2018) mentioned that rehabilitation process included the type, time, and dosage of therapy have contributed in recovery result for stroke patient. Intervention through reciting the holy Qur'an which has been applied by the researcher have given the stimulation from the bottom up and top down phenomenon interaction path. The term top down means where the vital organ (brain and heart) determine the other organ's work. In contrast, the bottom up phenomenon, stimulation through reciting, listening, breathing, and other bodies activity also can influence the brain work activities. Reciting the holy Qur'an activity can both stimulate and interact between brain and motor function (speaking organ) which will also influence the autonomy neuron (Sofro \& Kadarsih, 2013).

Reciting the holy Qur'an is managed by the regulation called Tajweed (exact verbalization) (Nayef \& Wahab, 2018). Phonetic from Qur'an can give big effect to the semantic, absorbing words and phrases from Al-Qu'an. Furthermore, sound and rhythm from Qur'an phonetic produced special voice through the management of letters and words in Qur'an while read or verbalized used voice (Kalani et al., 2016). In other study also mentioned that rhythm and harmony from the holy Qur'an voices which being listened can influence the memory system of brain function (Hojjati et al., 2014).

Reading-based Therapy Using the Holy Qur'an in Improving the Spirituality Level. Patient's ill problem should not only be viewed from the physical problem, but more holistic view through bio-psycho-social and spiritual view with their mission a servant of Allah and caliph of Allah's in life. Nurses supposed to provide and involving the patient to invite them in various religious activities to fulfill their spirituality need (Pratiwi et al., 2018). Spirituality was a process of seeking the meaning of life, felling to be connected with something higher and having a selftranscendence (Weathers et al., 2016). A 
person healthy was related to the physical, psychological, social, cultural, and spiritual factor balance. Spiritual was an important thing to the person to achieve the balance to improve health and life welfare degree also coping to the illness (Potter et al., 2016).

Hawari argued that reciting the holy
Qur'an is part of dhikr and praying, that is religious and spiritual elements that can provide mental strength as the basic concept of the healing process (as cited in Kusuma, 2017). Several verses describe that the Qur'an is a medicine (syifa'un) for humans, as in the verses of the Al-Qur'an (Al-Israa:82)

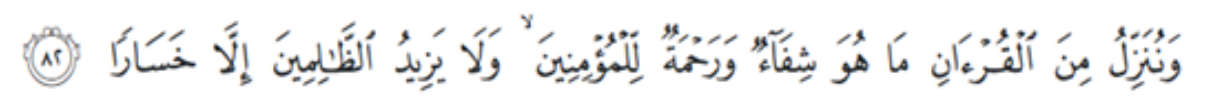

"We send down (stage by stage) in the Qur'an that which is a healing and a mercy to those who believe: to the unjust it causes nothing but loss after loss."

In order to obtain the potent medicine as stated in the Qur'an, people must serve to Allah faithfully, always obeying His commands without complaining and stay away from His prohibitions. Praying, reciting Qur'an, and being thankful also asking forgiveness when facing difficulties will be helpful to deal with life matters and being healthier. Al-Mu'awwidhat Surahs (al-Ikhlas, al-Falaq dan an-Nas) have own specialty. In other hand, surah al-Fatihah contains of prayer of the guidance, lordship, and mercy of Allah, almighty (Ahmad \& Ramli, 2016).

In supporting this study, study form Jafar et al. (2019) mentioned that reading and reciting the holy Qur'an can improve the quality of life. The one who reciting and understanding Qur'an can gain understanding about the meaning of life and have a good health spirituality. The one who has good spirituality experience will be easier to forgive, accepting the difficulties/illnesses, death and have a good quality of life (Potter et al., 2016).

Stroke and aphasia are chronic diseases. The patient rehabilitation requires long-term treatment that involves family care. It is also important to improve the spiritual well-being of the patient's family through interventions such as a bereavement live-review to maximize care in chronic patients (A'la et al., 2017).

In this study, also found that there was a significant difference in control group before and after treatment. There are several factors which can influence the personal spirituality.
Wiksuarini (2018) mentioned that one of them was illness. Health condition which can make someone to be suffered will produce the negative effect due to of the feeling being punished or leaved by the God. In other hand, this also can be a positive motivation to aware them to back to the God, the one who has control on him or her.

\section{Conclusion}

Reading therapy using the holy Qur'an can improve the speaking ability and spiritual level. This therapy can be used for a rehabilitation training activity for stroke patient with motor aphasia with speaking disorder. The other benefit was this therapy can be practiced at home independently by the patient as the therapy also as spiritual activity.

There are several limitations of this study during the study process, include:

1. Regarding to this reciting the holy Qur'an therapy effect, reciting Qur'an can be proposed as a nursing intervention to improve speaking disorder. There is another limitation, the reciting Qur'an therapy might be limited to be used with non-Moslems population, but it does not mean that nonMoslem populations are not allowed to read the Qur'an. The future study, it will be good to do further study to see the implication of this therapy to the non-Muslim population if possible.

2. In this study, the researcher did not randomize the respondent because have a limitation related to the amount of samples. For further study to minimize bias, research with the RCT method should be done.

3. In this study, patient has other factors 
Slamet Purnomo: The Effect of Reciting the Holy Qur'an to the Speaking Ability and Spirituality Level of Stroke

related to the aphasia such as the area of brain damage, damage location which could not be measured by the researcher since they were need for further diagnostic and other supporting tests. Financial limitation was the issue. For further study, it will be better to be explored more to have more maximum result with the diagnostic pictures.

\section{References}

Ahmad, K., \& Ramli, M. A. (2016). Understanding the Use of Ruqyah (Healing Method Based on The Quran and Hadith) in the Treatment of Disease: Analysis based on Fiqh al-Hadith Al-Imam Al-Bukhari. Al-BayanJournal Of Qur'an and Hadist Studies, 38. https://doi.org/10.1163/22321969-12340038

A'la, M. Z., Yosep, I., \& Agustina, H. R. (2017). Pengaruh Bereavement Life Review terhadap Kesejahteraan Spiritual pada Keluarga Pasien Stroke (bereavement life review effect to spiritual well-being to stroke patients family). Jurnal Keperawatan Padjadjaran, 5(2). https://doi.org/10.24198/ jkp.v5i2.526

Alawieh, A., Zhao, J., \& Feng, W. (2018). Factors affecting post-stroke motor recovery: Implications on neurotherapy after brain injury. Behavioural Brain Research, 340, 94-101. https://doi.org/10.1016/j. bbr.2016.08.029

Hojjati, A., Rahimi, A., Farehani, M. D., Sobhi-Gharamaleki, N., \& Alian, B. (2014). Effectiveness of Quran Tune on Memory in children. Procedia - Social and Behavioral Sciences, 114, 283-286. https://doi. org/10.1016/j.sbspro.2013.12.699

Jafar, I., Hartanto, O., Suminah, S., \& Sutisna Sulaeman, E. (2019). The Effect of Memorizing the Al Quran on Quality of Life in Stroke Patients With Aphasia Motoric Disorders. Global Journal of Health Science, 11, 29. https://doi.org/10.5539/gjhs. v11n7p29

Kalani, N., Modabber, M. H., Jahromi, H. K., \& Tafvizi, M. D. (2016). Quran's Phonetic and Marvelous Semantic Effects. Journal of Fundamental and Applied Sciences, 8(2S), 20. https://doi.org/10.4314/jfas.v8i2s.47

Khairunnisa, N., \& Fitriyani. (2014). Hemiparase Sinistra, Parase Nervus VII, IX, X, XII e.c Stroke Non-Hemorrhagic. Medula, $2(3), 8$.

Kim, E. S., \& Lemke, S. F. (2016). Behavioural and eye-movement outcomes in response to text-based reading treatment for acquired alexia. Neuropsychological Rehabilitation, 26(1), 60-86. https://doi.org/10.1080/09602 011.2014 .999688

Kusuma, A. B. (2017). Pendekatan Psychotherapy AlQuran Dalam Gangguan Kesehatan Mental (psychotherapy AlQuran approach in mental health disorders) (Suatu Kajian Psikologi Agama). Journal Al-Manar, 6(1), Article 1. https://doi.org/10.36668/jal. v6il.22

Lazar, R. M., \& Boehme, A. K. (2017). Aphasia As a Predictor of Stroke Outcome. Current Neurology and Neuroscience Reports, 17(11). https://doi.org/10.1007/ s11910-017-0797-z

Ministry of Health Indonesia. (2018). Profil Kesehatan Indonesia Tahun 2017 (Indonesia health profile). Kementrian Kesehatan RI.

Mohamad, S. P., Yusoff, Z. M., \& Adli, D. S. H. (2013). Sound Therapy Through Quranic Recitation in Dealing With Emotional And Verbal Motor Skills Problems of Children With Autism. International Journal of Quranic, 5(2), 21.

Nayef, E. G., \& Wahab, M. N. A. (2018). The Effect of Recitation Quran on the Human Emotions. International Journal of Academic Research in Business and Social Sciences, 8, (21). http://dx.doi.org/10.6007/IJARBSS/v8i2/3852

Palmer, R., Cooper, C., Enderby, P., Brady, M., Julious, S., Bowen, A., \& Latimer, N. (2015). Clinical and cost effectiveness of computer treatment for aphasia post stroke (Big CACTUS): Study protocol for 
Slamet Purnomo: The Effect of Reciting the Holy Qur'an to the Speaking Ability and Spirituality Level of Stroke

a randomised controlled trial. Trials, 16(1). https://doi.org/10.1186/s13063-014-0527-7

Potter, P. A., Perry, A. G., Stockert, P., \& Hall, A. (2016). Fundamentals of Nursing (9 ed). Elsevier Health Sciences.

Pratiwi, S. H., Sari, E. A., \& Mirwanti, R. (2018). Spiritual Needs of Post-Stroke Patients in the Rehabilitation Phase. Jurnal Keperawatan Padjadjaran, 6(3), Article 3. https://doi.org/10.24198/jkp.v6i3.989

Purnomo, A. M., Sengkey, L. S., \& Damopolii, C. A. (2016). Angka kejadian afasia pada stroke di Instalasi Rehabilitasi Medik RSUP Prof. Dr. R. D. Kandou Manado tahun 2015. Jurnal e-Clinic (eCl), 4(2), 6. https://doi. org/10.35790/ecl.v4i2.14346

Purnomo, S., \& Makiyah, S. N. N. (2019). Reading-Based Therapy in Aphasia: Literature Review. Dinamika Kesehatan (health dynamics). Jurnal Kebidanan Dan Keperawatan, 10(1), 349-360. https://doi. org/10.33859/dksm.v10i1.422

Richard, M. E. (2016). The Effect of an Intensive Oral Reading Program on Discourse in Chronic Mild Aphasia [Master's thesis, University of Connecticut]. University of Connecticut. Retrieved March 9, 2020, from https://opencommons.uconn.edu/cgi/ viewcontent.cgi article $=1840 \&$ context $=\mathrm{gs}$ theses

Singh, P., \& Pauranik, A. (2017). Effect of Reading and Writing Based Treatment Approaches on Verbal Output. Journal of Neurology and Neuroscience, 08(03). https:// doi.org/10.21767/2171-6625.1000194
Sofiatun, I., Kristiyawati, S. P., \& Purnomo, S. E. C. (2016). Efektifitas Terapi AIUEO Dan Terapi The Token Test Terhadap Kemampuan Berbicara Pasien Stroke Yang Mengalami Afasia Di RS Mardi Rahayu Kudus. Jurnal Ilmu Keperawatan Dan Kebidanan, 2(4), 9.

Sofro, Z. M., \& Kadarsih, S. (2013). Pengembangan Penggunaan Uji Schellong, Pemetaan Dan Pengelolaan Tonus Simpatis Hubungan antara Hasil Uji Schellong dengan Faktor Kepribadian,Pajanan Surat Al-Hujurat dan Status Saraf Otonom [Doctoral's disertation, Universitas Gadjah Mada]. Retrieved March 9, 2020, from http://etd.repository.ugm.ac.id/index. php mod $=$ penelitian detail\&sub $=$ Peneli tianDetail\&act $=$ view $\&$ typ $=$ html\&buku $\mathrm{id}=65895$

Weathers, E., McCarthy, G., \& Coffey, A. (2016). Concept Analysis of Spirituality: An Evolutionary Approach. Nursing Forum, 51(2), 79-96. https://doi.org/10.1111/ nuf.12128

WHO, (World Health Organization). (2015). The top 10 causes of death. Retrieved March 12, 2020 http://www.who.int/mediacentre/ factsheets/fs310/en/

Wiksuarini, E. (2018). Spiritualitas, Deperesi Dan Kualitas Hidup Pada Pasien Kanker Di Rumah Sakit Umum Daerah Provinsi NTB [Master's thesis, Universitas Muhammdiyah Yogyakarta]. Universitas Muhammadiyah Yogyakarta. Retrieve March 12, 2020, from http://repository.umy.ac.id/ handle/123456789/22328 